This is a self-archived version of an original article. This version may differ from the original in pagination and typographic details.

Author(s): Mökkönen, Mikael; Koskela, Esa; Procyshyn, Tanya; Crespi, Bernard

Title: Socio-Reproductive Conflicts and the Father's Curse Dilemma

Year: 2018

Version: Published version

Copyright: ㅇ 2018 The University of Chicago.

Rights: In Copyright

Rights url: http://rightsstatements.org/page/InC/1.0/?language=en

Please cite the original version:

Mökkönen, M., Koskela, E., Procyshyn, T., \& Crespi, B. (2018). Socio-Reproductive Conflicts and the Father's Curse Dilemma. American Naturalist, 192(2), 250-262.

https://doi.org/10.1086/698216 


\title{
Socio-reproductive Conflicts and the Father's Curse Dilemma
}

\author{
Mikael Mokkonen, ${ }^{1,2, \dagger}$ Esa Koskela, ${ }^{2}$ Tanya Procyshyn, ${ }^{1}$ and Bernard Crespi ${ }^{1}$ \\ 1. Department of Biological Sciences, Simon Fraser University, 8888 University Drive, Burnaby, British Columbia V5A 1S6, Canada; \\ 2. Department of Biological and Environmental Science, PO Box 35, University of Jyväskylä, 40014 Jyväskylä, Finland \\ Submitted October 14, 2017; Accepted March 30, 2018; Electronically published May 31, 2018
}

\begin{abstract}
A BST RAC T: Evolutionary conflicts between males and females can manifest over sexually antagonistic interactions at loci or over sexually antagonistic interests within a locus. The latter form of conflict, intralocus sexual conflict, arises from sexually antagonistic selection and constrains the fitness of individuals through a phenotypic compromise. These conflicts, and socio-reproductive interactions in general, are commonly mediated by hormones, and thus predictive insights can be gained from studying their mediating effects. Here, we integrate several lines of evidence to describe a novel, hormonally mediated reproductive dilemma that we call the father's curse, which results from an intralocus conflict between mating and parental efforts. Essentially, a genetic locus exerts pleiotropic and antagonistic effects on the mating effort of one individual and the parental effort of a related individual who is the primary provider of parental care. We outline the criteria for operation of the father's curse dilemma, provide evidence of the phenomenon, and discuss the predictions and outcomes arising from its dynamics. By integrating the effects of hormones into socio-reproductive conflicts and socio-reproductive effort, clearer links between genotypes, phenotypes, and fitness can be established.
\end{abstract}

Keywords: genomic conflict, sexual conflict, parent-offspring conflict, testosterone, oxytocin, bank vole.

Evolutionary Conflicts and the Father's Curse Dilemma

Evolutionary conflicts in reproduction arise due to divergences in evolutionary interests of loci depending on whether they are in males, females, parents, or offspring (Arnqvist and Rowe 2005; Bonduriansky and Chenoweth 2009; Mokkonen et al. 2016; Rowe et al. 2018; table 1). Such conflicts result in fitness trade-offs that can constrain adaptation to phenotypic optima during reproduction (Trivers 1974; Chippindale et al. 2001; Chapman et al. 2003; Arnqvist and Rowe 2005; Bonduriansky and Chenoweth 2009; Cox and Calsbeek 2009;

\footnotetext{
* These articles originated as the 2017 Vice Presidential Symposium presented at the annual meetings of the American Society of Naturalists in Portland, Oregon.

$\dagger$ Corresponding author; email: mikael.mokkonen@gmail.com.

ORCIDs: Mokkonen, http://orcid.org/0000-0003-1812-7280; Koskela, http:// orcid.org/0000-0002-9418-5733; Procyshyn, http://orcid.org/0000-0003-1266 -6697 .

Am. Nat. 2018. Vol. 192, pp. 250-262. (C) 2018 by The University of Chicago. 0003-0147/2018/19202-58016\$15.00. All rights reserved. DOI: $10.1086 / 698216$
}

Pennell and Morrow 2013). Prezygotic reproductive investment differs considerably between the sexes due to anisogamy and the resulting difference in reproductive opportunities for females and males. Consequently, males are typically the sex that is under stronger sexual selection: a biased operational sex ratio toward males gives rise to greater variance in reproductive success and greater opportunity for selection compared to females (Clutton-Brock 2007). Evolutionary conflict can arise between males and females when reproductive interests diverge to such an extent that sexually antagonistic selection acts on phenotypes with sex-specific fitness optima in females compared to males. Such sexual conflict can take the form of interlocus sexual conflict, whereby the conflict is between coevolving loci in females and males (Chapman et al. 2003; Arnqvist and Rowe 2005), or intralocus sexual conflict, whereby the conflict occurs within a locus that exerts sexually antagonistic effects on fitness (Pischedda and Chippindale 2006; Bonduriansky and Chenoweth 2009; Pennell and Morrow 2013). In addition to these prezygotic differences in reproductive investment between the sexes, postzygotic reproductive investment also differs between females and males due to factors such as greater paternity uncertainty experienced by fathers, a greater benefit or lower cost to the sex providing care, and the action of sexual selection (Trivers 1972; Clutton-Brock 1991; Andersson 1994; Arnqvist and Rowe 2005; McNamara and Wolf 2015). These asymmetries in pre- and postzygotic investment define the varying sex roles of females and males and indicate that there are many opportunities for conflict to arise during reproduction.

Mating and caring for offspring are reproductive components that trade off with regard to an individual's finite resources (Dawson 1996; Stiver and Alonzo 2009). Owing to divergent sex roles, males typically employ greater mating effort, while females expend more parental effort in reproduction (Queller 1997; Kokko and Jennions 2008; Stiver and Alonzo 2009). In both sexes, but more so in males, an individual that maximizes mating effort is expected to increase their fitness through this component of reproductive success: selection will primarily favor those traits that yield higher mating success and more offspring. Conversely, an individual that maximizes their parental effort is also 
Table 1: Comparison of features in types of evolutionary conflict

\begin{tabular}{|c|c|c|c|c|c|}
\hline $\begin{array}{l}\text { Type of effort } \\
\text { involved }\end{array}$ & $\begin{array}{l}\text { Form of } \\
\text { evolutionary } \\
\text { conflict }\end{array}$ & $\begin{array}{l}\text { Nature of } \\
\text { genetic } \\
\text { conflict }\end{array}$ & $\begin{array}{l}\text { Entities in } \\
\text { conflict }\end{array}$ & $\begin{array}{l}\text { Within or } \\
\text { between } \\
\text { generations }\end{array}$ & $\begin{array}{l}\text { Distinguishing } \\
\text { feature }\end{array}$ \\
\hline Parental effort & Parent-offspring & Interlocus & Parent and offspring & Between & $\begin{array}{l}\text { Antagonistic coevolution } \\
\text { between interacting } \\
\text { traits involved in provi- } \\
\text { sioning and soliciting } \\
\text { resources during paren- } \\
\text { tal care }\end{array}$ \\
\hline Parental effort & Imprinting & Intralocus & $\begin{array}{l}\text { Alleles in locus; } \\
\text { maternal/paternal } \\
\text { asymmetry in } \\
\text { expression }\end{array}$ & Between & $\begin{array}{l}\text { Parent-of-origin silencing } \\
\text { of alleles that maintains } \\
\text { conflict between paternal } \\
\text { and maternal interests } \\
\text { within the offspring }\end{array}$ \\
\hline Mating effort & $\begin{array}{l}\text { Intralocus sexual } \\
\text { conflict }\end{array}$ & Intralocus & $\begin{array}{l}\text { Brother and sister, fa- } \\
\text { ther and daughter, } \\
\text { mother and son }\end{array}$ & $\begin{array}{l}\text { Within or } \\
\text { between }\end{array}$ & $\begin{array}{l}\text { Sexually antagonistic tug- } \\
\text { of-war over a locus }\end{array}$ \\
\hline Mating effort & $\begin{array}{l}\text { Interlocus sexual } \\
\text { conflict }\end{array}$ & Interlocus & Male and female mates & Within & $\begin{array}{l}\text { Sexually antagonistic } \\
\text { coevolution between } \\
\text { different loci }\end{array}$ \\
\hline $\begin{array}{l}\text { Mating and } \\
\text { parental } \\
\text { efforts }\end{array}$ & $\begin{array}{l}\text { Father's curse } \\
\text { dilemma }\end{array}$ & Intralocus & $\begin{array}{l}\text { Mother and son, father } \\
\text { and daughter }\end{array}$ & Between & $\begin{array}{l}\text { A locus exerts antagonistic } \\
\text { fitness effects on mating } \\
\text { effort in one individual } \\
\text { and parental effort in } \\
\text { the other }\end{array}$ \\
\hline
\end{tabular}

Note: For the relatedness of individuals, it is assumed that there is no inbreeding or hermaphroditism.

expected to increase their fitness, especially through the component of offspring survival: selection will primarily favor those traits that produce higher-quality care of offspring during the postnatal period. Investments in mating effort and parental effort frequently result in parent-parent conflicts and parent-offspring conflicts, respectively, though clear demarcation between these various forms of conflict has become increasingly more challenging (Godfray and Parker 1992; Parker et al. 2002; Royle et al. 2004; Meunier and Kolliker 2012; Patten et al. 2014). For example, interlocus sexual conflict results when female reproductive success is constrained by assuming greater parental care, while male reproductive success is enhanced by obtaining more time for mating activities, thus extending the phenotypic realm of sexual conflict beyond premating social interactions (Arnqvist and Rowe 2005; Wedell et al. 2006; Aloise King et al. 2013; McNamara and Wolf 2015). When the same allele influences traits associated with both mating and parental efforts between individuals, an intralocus conflict that we call the father's curse dilemma may arise.

The father's curse dilemma is an evolutionary conflict between parental effort in females and mating effort in males that arises due to pleiotropy and sexually antagonistic selection on a shared locus (fig. 1). We refer to this conflict as the father's curse dilemma because it results in a trade-off between mating effort of males that experience greater variance (skew) in reproductive success and parental effort of females that are the primary caregivers during the weaning period (Clutton-Brock 2007; Kokko and Jennions 2008; Aloise King et al. 2013; fig. 1). We emphasize here that although such a conflict between mating and parental efforts has deleterious fitness consequences for both sexes, males have the potential to suffer larger fitness costs due to their greater variance in reproductive success compared to females; given such asymmetry in reproductive success between the sexes, the number of reproducing males is by definition less than the number of reproducing females in a given population. The genomic conflict occurs within a locus pleiotropically linked to both mating and parental efforts, which can impact fitness at different life stages (table 1). Early-life survival of males (during postnatal care) is predicted to be influenced by indirect genetic effects of the mother whereby the mother exerts nongenetic maternal effects associated with parental care on the survival of the offspring. Consequently, juvenile males that have higher-quality parental care and survive the juvenile period are predicted to fare worse in reproductive competition as adults due to the action of the sexually antagonistic locus. Similarly, daughters of reproductively successful males are predicted to provide a lower level of parental care (fig. 1). The father's curse dilemma thus relies on the action of a gene with antagonistic fitness effects to give rise to the evolution- 
A

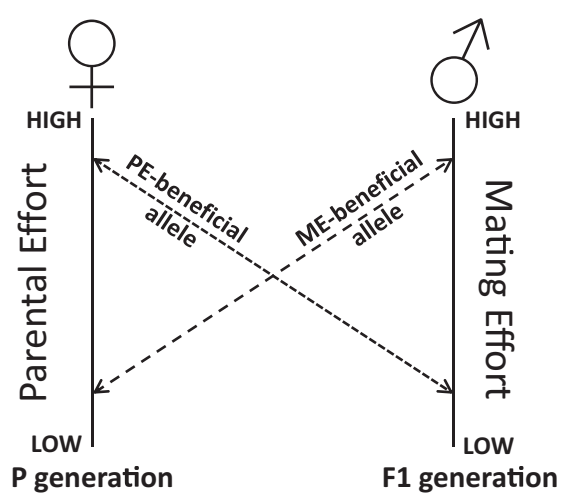

B

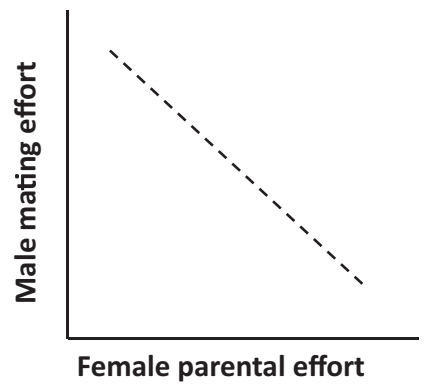

C

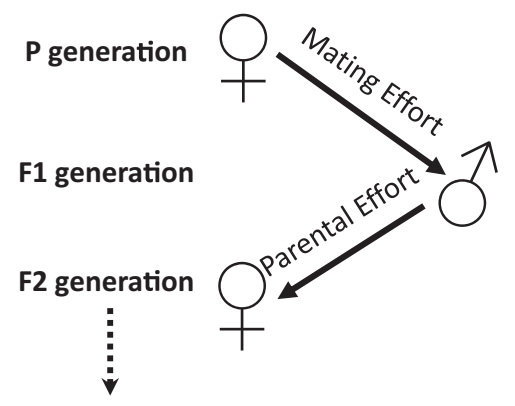

Figure 1: Antagonistic fitness effect of an allele on parental and maternal efforts between generations. A, An allele that benefits parental effort (PE-beneficial allele) has a corresponding negative effect on mating effort, while an allele that benefits mating effort (ME-beneficial allele) has a corresponding negative fitness effect on parental effort. $B$, The predicted negative fitness correlation between male mating effort and female parental effort. $C$, The sexually antagonistic allele through generations, exerting alternating fitness costs on male mating effort and female parental effort.

ary conflict between sexes and ontogenetic stages, with the additional consideration of indirect effects of parental investment (Chippindale et al. 2001; Rice and Chippindale 2001). Such conflicts are expected to be mediated, in particular, by the presence of genetically based hormone signaling systems that exert strong pleiotropic effects on mating and parental efforts due to the central role of hormones in the pre- and postzygotic phases of reproduction (Mokkonen and Crespi 2015; Mokkonen et al. 2016).

This article details how fitness trade-offs between mating effort and parental effort that are characteristic of the father's curse dilemma can lead to evolutionary conflict (fig. 1). We outline theoretical criteria for the father's curse dilemma; provide evidence for this dilemma primarily from mammalian taxa in the context of the testosterone, arginine vasopressin, and oxytocin hormone systems; and describe predictions as well as evolutionary outcomes that derive from this phenomenon.

\section{Requirements for the Father's Curse Dilemma}

\section{A Sexually Antagonistic Locus with Hormonally Pleiotropic Effects on Mating and Parental Efforts}

Through pleiotropy, a genetic locus can exert effects on multiple fitness-relevant traits (Williams 1957; McGuigan et al. 2011). While it is still unclear whether genetic variation associated with mating success is more or less pleiotropic compared to the rest of the genome, we can focus on biological systems with known pleiotropic effects on mating effort: hormone signaling systems (Fitzpatrick 2004; Mank et al. 2008; Cox et al. 2009). Recent evidence indicates that testosterone (T), oxytocin (OXT), and arginine vasopressin
(AVP) belong to sexually antagonistic hormone systems (Garver-Apgar et al. 2011; Mills et al. 2012; Gerlach and Ketterson 2013; Peterson et al. 2014; Mokkonen and Crespi 2015; Lonn et al. 2017). Hormone systems are influenced through both the fine-tuning action of selection and shortand longer-term responses to environmental stimuli (Wingfield et al. 1990; Ketterson and Nolan 1999; Donaldson and Young 2008; Mills et al. 2009; Hau and Wingfield 2011; Lonn et al. 2017). Hormones mediate fitness-related traits through their effects on behavior and physiology and are often specific in profile to a given sex, life stage, or social context. Steroid hormones such as $\mathrm{T}$ promote the growth and development of physiological and physical characteristics that are important for reproduction, especially in males, and are also centrally responsible for mediating reproductive behaviors (Adkins-Regan 2005; Zysling et al. 2006; Cox et al. 2009; John-Alder et al. 2009; Mills et al. 2009; Mokkonen and Crespi 2015; Mokkonen et al. 2016). The neuropeptide OXT also exerts pleiotropic effects on reproductive physiology and behaviors that primarily manifest during postnatal interactions between parent and offspring (Donaldson and Young 2008; Lee et al. 2009; McCall and Singer 2012; Hammock 2015; Crespi 2016). The closely related neuropeptide AVP is primarily responsible for mediating prosocial behaviors and aggression, including social aggression, dominance behavior, male bonding, and anxiety (Young et al. 1999; Donaldson and Young 2008; McCall and Singer 2012). These hormones actively shape fitness through their effects on both reproductive traits and social interactions: when phenotypic optima differ between individuals over expression of, or internal receptor-driven responses to, a given hormone, conflict is expected in the hormonally mediated trait and potentially within the genome. 
Research in avian and mammalian taxa has shown that $\mathrm{T}$ has opposing effects on mating and parental efforts within individuals (Clark and Galef 1999; McGlothlin et al. 2007; Mascaro et al. 2013; Roney and Gettler 2015). The pleiotropic effect of $\mathrm{T}$ manifests in primary and secondary sexual traits, including reproductive behaviors (Ketterson and Nolan 1999; Cox et al. 2009; John-Alder et al. 2009; Malo et al. 2009; Mills et al. 2009; Mokkonen et al. 2012; Rosvall et al. 2012). The resulting antagonistic effect of $\mathrm{T}$ on mating behavior in females compared to males underlines the direct importance and sex specificity of this hormone on mating effort (Mokkonen et al. 2012). However, given the social-context specificity of $\mathrm{T}$, potential fitness benefits that it confers in mating effort may trade off with other fitness domains, primarily parental effort (Gray et al. 2002; Gray 2003; McGlothlin et al. 2007; Alvergne et al. 2009; Kuzawa et al. 2009; Muller et al. 2009; tables 2, 3). For example, an endocrine response of higher $\mathrm{T}$ in parents caring for offspring can result in lower parental attentiveness, greater aggression, and higher probability of deserting the offspring (Cavigelli and Pereira 2000; Mills et al. 2012; Rosvall 2013; Saltzman and Ziegler 2014). To potentially mitigate this cost of $\mathrm{T}$, mammalian fathers in some species downregulate $\mathrm{T}$ during the critical period of postnatal care of offspring (Gray et al. 2002; Alvergne et al. 2009; Mascaro et al. 2013; Saltzman and Ziegler 2014). Thus, accounting for trade-offs between mating effort and parental effort will provide important insights into the fitness benefits and costs of sexually antagonistic traits mediated by $\mathrm{T}$.

\section{Uniparental Care of Offspring}

Another requirement for the operation of the father's curse is that an individual belongs to a species in which uniparental care (e.g., maternal care) is the primary form of resource provisioning during the postnatal period. This asymmetry in parental effort is required for the evolutionary conflict between mating and parental efforts to be realized: lower parental effort by males allows them to invest more in mating effort relative to females. Among most taxonomic groups, biparental care is the exception, and males do not experience the fitness constraints and resource demands of parental care (Reynolds et al. 2002; Lukas and CluttonBrock 2012). A phylogenetic comparison of vertebrate taxa has demonstrated that uniparental care is probably the ancestral mode (Reynolds et al. 2002). Most mammals (as well as other vertebrate taxa) adhere to this form of parental care, and as a result offspring survival is mainly determined by traits that optimize maternal care behaviors, while fathers influence offspring fitness only genetically (fig. 2). Consequently, parental care likely evolves independently in females and males due to sex-specific expression and selection on associated traits (Walling et al. 2008; Bendesky et al. 2017). This presumed uncoupling of parental care behavior in females and males makes it less likely that selection on parental effort can reduce the fitness costs of the father's curse dilemma through correlated selection on the opposite parental sex; selecting for good-quality paternal care is unlikely to eliminate the fitness costs associated with the father's curse.

\section{Context Specificity of the Selected Locus Determines Fitness Outcomes}

As previously outlined, the father's curse dilemma is likely to manifest in a fitness trade-off between the parental effort of females and the mating success of males (fig. 1). In practical terms, a female that provides high-quality parental care will produce sons that are relatively less competitive in reproduction. Similarly, a male with high reproductive success will produce daughters that provide a relatively lower quality of parental care. The conflict therefore exists between fathers and daughters, or mothers and sons. However, this observation does not necessarily exclude genomic conflicts between same-sex parent-offspring combinations if a locus can be shown to antagonistically impact parenting effort in one individual and mating effort in a related individual.

While sexual conflicts are usually characterized as evolutionary conflicts between females and males, conflicts between parents and offspring are typically characterized as intergenerational conflicts between immediate relatives. However, in both cases, the locus or loci in conflict exert context-specific effects on fitness that depend on the genome or life stage in which the locus is expressed (e.g., female vs. male genome, juvenile vs. adult life stage, type of social interaction). Sexually antagonistic loci confer fitness benefits on one sex when found in its genome and fitness costs when located in the genome of the opposite sex (Chippindale et al. 2001; Chapman et al. 2003; Arnqvist and Rowe 2005; Bonduriansky and Chenoweth 2009; Cox and Calsbeek 2009). Similarly, imprinted genes exert conflicting effects on fitness in offspring due to the parent-of-origin manner of gene expression (Patten et al. 2013; Haig 2014). A maternally expressed (paternally silenced) locus such as IGF2R within the offspring may thus introduce similar conflictual dynamics whereby the maternal optimum (in this case, suppressed offspring growth in utero) is mismatched with the offspring optimum (greater offspring growth; Haig 2004; Mokkonen and Crespi 2015; Saldivar Lemus et al. 2017). Thus, while we focus on sexually antagonistic loci in this article, it is conceivable that any locus that exerts such antagonistic effects could potentially result in father's curse-like dynamics.

In general, the optimal "social phenotype" for attaining a mate differs from the phenotype for optimal parental care. For example, intramale aggression and dominance behavior (promoted with higher T) may yield a higher probability 
Table 2: Evidence for aspects of the father's curse dilemma from mammalian testosterone and oxytocin hormone systems that show effects on parental effort

\begin{tabular}{|c|c|c|c|c|}
\hline $\begin{array}{l}\text { Hormone and } \\
\text { study type }\end{array}$ & Species & Evidence in support of father's curse & $\begin{array}{l}\text { Evidence of sex } \\
\text { difference }\end{array}$ & Citations \\
\hline \multicolumn{5}{|l|}{ Testosterone: } \\
\hline Hormone levels & Humans & Lower $\mathrm{T}$ in fathers and mothers & $\begin{array}{l}\text { No; } T \text { decrease in } \\
\text { both sexes }\end{array}$ & $\begin{array}{l}\text { Kuzawa et al. 2009, } \\
\text { 2010; Muller et al. } \\
\text { 2009; Gettler et al. } \\
2011\end{array}$ \\
\hline Hormone levels & Humans & $\begin{array}{l}\text { More } \mathrm{T} \text { variability associated with } \\
\text { more optimal parenting in fathers, } \\
\text { less optimal parenting in mothers }\end{array}$ & $\begin{array}{l}\text { Yes; opposite associa- } \\
\text { tion between } \mathrm{T} \text { and } \\
\text { parenting in males } \\
\text { and females }\end{array}$ & $\begin{array}{l}\text { Endendijk et al. } \\
\quad 2016\end{array}$ \\
\hline Hormone levels & Marmosets & Decreased $\mathrm{T}$ in fathers & NA; males only & Nunes et al. 2000 \\
\hline Hormone levels & Marmosets & Exposure to infant scent lowers males' $\mathrm{T}$ & NA; males only & Prudom et al. 2008 \\
\hline Hormone levels & Black redstarts & $\begin{array}{l}\text { Short-term, natural peaks in } \mathrm{T} \text { (induced } \\
\text { by GnRH injections) temporarily } \\
\text { suppressed paternal behavior } \\
\text { (offspring feeding) }\end{array}$ & NA; males only & $\begin{array}{l}\text { Goymann and } \\
\text { Flores Dávila } 2017\end{array}$ \\
\hline \multicolumn{5}{|l|}{ Oxytocin: } \\
\hline Administration & Marmosets & $\begin{array}{l}\text { OXT administration increases food } \\
\text { transferring by fathers to offspring }\end{array}$ & NA; males only & $\begin{array}{l}\text { Saito and Nakamura } \\
2011\end{array}$ \\
\hline Hormone levels & Marmosets & $\begin{array}{l}\text { OXT positively associated with infant } \\
\text { care }\end{array}$ & $\begin{array}{l}\text { Yes; higher OXT in } \\
\text { breeding females }\end{array}$ & $\begin{array}{l}\text { Finkenwirth et al. } \\
2016\end{array}$ \\
\hline Administration & Marmosets & $\begin{array}{l}\text { OXT decreased latency to respond } \\
\text { to infant stimuli among males }\end{array}$ & $\begin{array}{l}\text { Yes; OXT decreased } \\
\text { latency for males, } \\
\text { not females }\end{array}$ & $\begin{array}{l}\text { Taylor and French } \\
2015\end{array}$ \\
\hline Administration & Meerkats & $\begin{array}{l}\text { Peripheral OXT increased cooperative } \\
\text { behavior of adults, including feeding } \\
\text { and guarding of pups }\end{array}$ & $\begin{array}{l}\text { NA; did not test for } \\
\text { sex difference }\end{array}$ & $\begin{array}{l}\text { Madden and } \\
\text { Clutton-Brock } \\
2011\end{array}$ \\
\hline Antagonist & Prairie voles & $\begin{array}{l}\text { Neonatal injection of OXT antagonist } \\
\text { reduced alloparental care near } \\
\text { weaning }\end{array}$ & $\begin{array}{l}\text { Yes; significant effect } \\
\text { in males only }\end{array}$ & Bales et al. 2004 \\
\hline Hormone levels & Humans & $\begin{array}{l}\text { Higher-plasma OXT associated with } \\
\text { greater parental touch }\end{array}$ & NA & Feldman et al. 2012 \\
\hline Hormone binding & Meadow voles & $\begin{array}{l}\text { Experienced fathers had greater OXT } \\
\text { binding in AON, bed nucleus of the } \\
\text { stria terminalis, LS, and lateral } \\
\text { amygdala }\end{array}$ & NA; males only & Parker et al. 2001 \\
\hline Hormone levels & Humans & $\begin{array}{l}\text { New parents show increases in OXT } \\
\text { over } 6 \text { months }\end{array}$ & $\begin{array}{l}\text { No; OXT increases in } \\
\text { mothers and fathers }\end{array}$ & Gordon et al. 2010 \\
\hline Hormone levels & Humans & $\begin{array}{l}\text { High levels of contact with infant } \\
\text { associated with OXT increase }\end{array}$ & $\begin{array}{l}\text { No; similar OXT levels } \\
\text { and increases in } \\
\text { mothers and fathers }\end{array}$ & Feldman et al. 2010 \\
\hline Administration & Humans & $\begin{array}{l}\text { OXT increases fathers' neural response } \\
\text { to images of their children }\end{array}$ & NA; fathers only & Li et al. 2017 \\
\hline
\end{tabular}

Note: $\mathrm{AON}=$ anterior olfactory nucleus; $\mathrm{GnRH}=$ gonadotropin-releasing hormone; $\mathrm{LS}=$ lateral septum; $\mathrm{NA}=$ not applicable; OXT = oxytocin; $\mathrm{T}=$ testosterone.

of mating success, while evidence indicates that females (and to a lesser extent males in biparental taxa such as humans) experience greater OXT levels after parturition that facilitate parent-offspring bonding, parental attentiveness, emotional empathy, and physiological effects such as the promotion of lactation (McCall and Singer 2012; Ham- mock 2015; Crespi 2016; tables 2,3). The affiliative effects of OXT are beneficial for both sexes during this period of parental care; however, such an affiliative effect on male mating behavior - particularly during the competition for mates - is predicted to be costly in terms of lower mating success since greater OXT levels in males are predicted to reduce competi- 
Table 3: Evidence for aspects of the father's curse dilemma from mammalian testosterone and oxytocin hormone systems that show effects on mating effort

\begin{tabular}{|c|c|c|c|c|}
\hline $\begin{array}{l}\text { Hormone and } \\
\text { study type }\end{array}$ & Species & Evidence in support of father's curse & $\begin{array}{l}\text { Evidence of sex } \\
\text { difference }\end{array}$ & Citations \\
\hline \multicolumn{5}{|l|}{ Testosterone: } \\
\hline Hormone levels & $\begin{array}{l}\text { Père David's } \\
\text { deer }\end{array}$ & $\begin{array}{l}\text { Higher-plasma } \mathrm{T} \text { associated with higher } \\
\text { dominance and mating }\end{array}$ & NA; males only & Chunwang et al. 2004 \\
\hline Hormone levels & Bank voles & $\begin{array}{l}\text { High- } \mathrm{T} \text { males show greater social status; } \\
\text { exogenous } \mathrm{T} \text { increases social status, } \\
\text { mate searching, reproductive success }\end{array}$ & NA; males only & Mills et al. 2007, 2009 \\
\hline Hormone levels & Bank voles & $\begin{array}{l}\text { Selection for } \mathrm{T} \text { associated with greater } \\
\text { male reproductive success, lower } \\
\text { female reproductive success, and vice } \\
\text { versa }\end{array}$ & Yes & $\begin{array}{l}\text { Mokkonen et al. } \\
\text { 2011, 2012; Mills } \\
\text { et al. } 2012\end{array}$ \\
\hline Hormone levels & Humans & $\begin{array}{l}\text { Positive association between } \mathrm{T} \text { and } \\
\text { mating success }\end{array}$ & NA; males only & Peters et al. 2008 \\
\hline Hormone levels & Humans & $\begin{array}{l}\text { Polyamorous individuals have highest } \\
\text { T levels }\end{array}$ & $\begin{array}{l}\text { No; effect in males } \\
\text { and females }\end{array}$ & $\begin{array}{l}\text { van Anders et al. } \\
2007\end{array}$ \\
\hline Hormone levels & Baboons & $\begin{array}{l}\text { T positively associated with mating effort } \\
\text { and parental effort }\end{array}$ & NA; males only & Onyango et al. 2013 \\
\hline Hormone levels & Rhinoceros & $\mathrm{T}$ positively associated with mating effort & NA; males only & Edwards et al. 2015 \\
\hline Administration & House mouse & $\begin{array}{l}\mathrm{T} \text { administration promotes copulatory } \\
\text { behavior }\end{array}$ & NA; males only & $\begin{array}{l}\text { James and Nyby } \\
2002\end{array}$ \\
\hline \multicolumn{5}{|l|}{ Oxytocin: } \\
\hline Administration & Marmosets & $\begin{array}{l}\text { OXT administration delayed sexual so- } \\
\text { licitation behavior toward a stranger; } \\
\text { no effect on sexual behavior toward } \\
\text { long-term partner }\end{array}$ & $\begin{array}{l}\text { NA; effect in males } \\
\text { and females }\end{array}$ & Cavanaugh et al. 2014 \\
\hline Administration & Marmosets & $\begin{array}{l}\text { OXT administration induced preference } \\
\text { for partner over stranger }\end{array}$ & $\begin{array}{l}\text { No; effect in both } \\
\text { males and females }\end{array}$ & Smith et al. 2010 \\
\hline Administration & Rats & $\begin{array}{l}\text { OXT administration reduced offensive } \\
\text { aggression and increased social explo- } \\
\text { ration toward unfamiliar male, } \\
\text { strengthened bond between mates }\end{array}$ & NA; tested males only & Calcagnoli et al. 2015 \\
\hline Association & Prairie voles & $\begin{array}{l}\text { Higher OXT receptor density in the } \\
\text { nucleus accumbens associated } \\
\text { with greater monogamy }\end{array}$ & NA; tested males only & Ophir et al. 2012 \\
\hline Administration & Prairie voles & $\begin{array}{l}\text { Centrally administered OXT enhanced } \\
\text { mating-induced partner preference }\end{array}$ & $\begin{array}{l}\text { No; effect in both } \\
\text { males and females }\end{array}$ & Cho et al. 1999 \\
\hline Antagonist & Prairie voles & $\begin{array}{l}\text { OXT antagonist prevents mating- } \\
\text { induced partner preference }\end{array}$ & $\begin{array}{l}\text { No; effect in both } \\
\text { males and females }\end{array}$ & $\begin{array}{l}\text { Young et al. 2001; } \\
\text { Johnson et al. } 2016\end{array}$ \\
\hline
\end{tabular}

Note: $\mathrm{NA}=$ not applicable; $\mathrm{OXT}=$ oxytocin; $\mathrm{T}=$ testosterone.

tive motivation and aggression (Dhakar et al. 2012; Calcagnoli et al. 2015). Thus, the context specificity of hormones can lead to trade-offs between mating effort and parental effort.

Most mammalian species meet the criteria for the father's curse dilemma, given that most of these systems feature overlapping generations, practice uniparental care by the mother (or mainly maternal care), share anciently conserved hormone signaling systems that are associated with sexually antagonistic traits, and involve sophisticated social interactions (Reynolds et al. 2002; Donaldson and Young 2008; Mokkonen and Crespi 2015). Next, we focus on one such species, the bank vole (Myodes glareolus), to illustrate how fitness-related hormones demonstrate the father's curse dilemma in this species.

\section{Case Study of the Father's Curse in Voles Bank Vole System}

Bank voles are broadly distributed throughout Europe, primarily inhabiting forests and fields (Hansson 1979; Bujalska and Hansson 2000). The densities of field populations have 

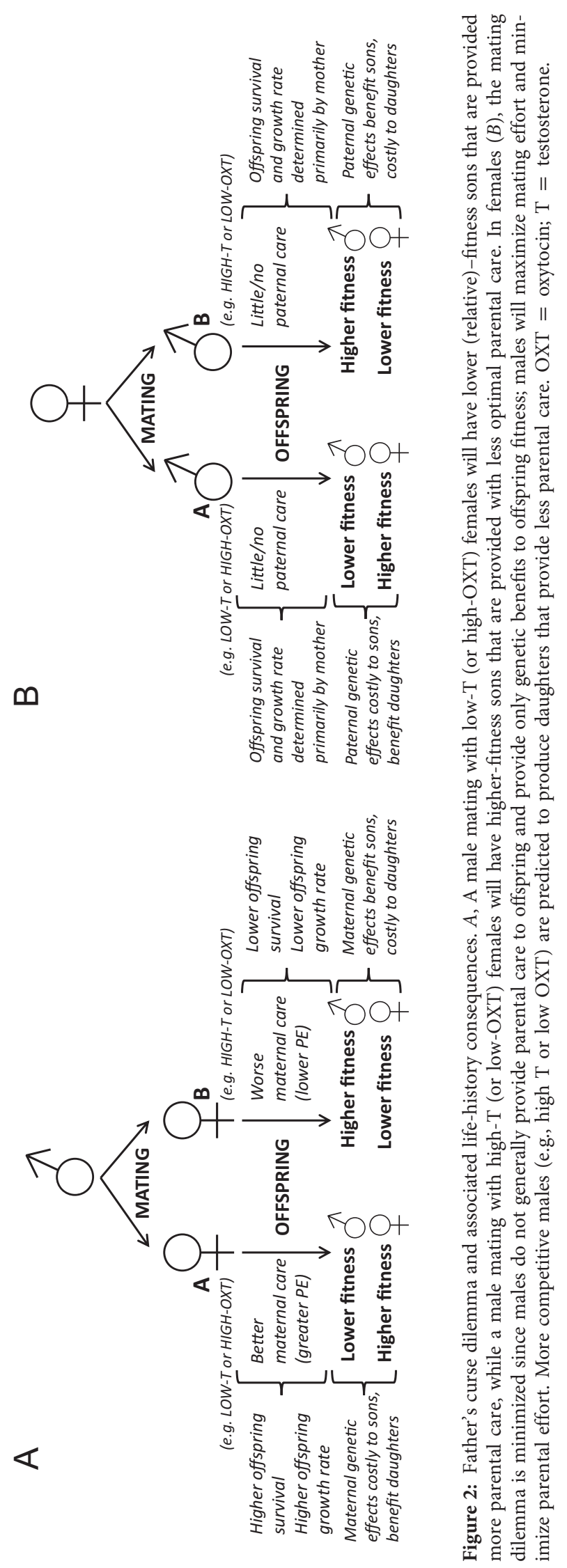

This content downloaded from 130.234.074.034 on July 19, 2018 01:01:08 AM All use subject to University of Chicago Press Terms and Conditions (http://www.journals.uchicago.edu/t-and-c). 
implications for fitness, as females are territorial and must contend with infanticidal threats during the breeding season (Koskela et al. 1997; Ylönen et al. 1997; Poikonen et al. 2008). The mating system is polygynandrous, whereby males and females mate with multiple individuals (Shuster and Wade 2003; Mills et al. 2007, 2014; Mokkonen et al. 2012). Furthermore, males establish dominance hierarchies in reproductive competition that are mediated by testosterone (Mills et al. 2009; Mokkonen et al. 2011; Lemaître et al. 2012). While females, and not males, provide parental care to offspring, both sexes can increase their reproductive success by acquiring additional mates in a reproductive bout; females are mechanically induced to ovulate more with each additional mate (Clarke et al. 1970; Mokkonen et al. 2012; Mills et al. 2014). Given the propensity of this species to mate with multiple partners, previous work has shown that up to $50 \%$ of field litters are sired by multiple males (Mills et al. 2007). However, the prevalence of multiple mating may be even higher, as another recent estimate of lab-based mating trials indicated that approximately $65 \%$ of females mated with multiple males, which supports other work that has found an appreciable level of postcopulatory competition in the form of sperm competition in this species (Lemaitre et al. 2011, 2012; Mokkonen et al. 2016). These studies indicate that the mating system of bank voles possesses great potential for evolutionary conflicts between mates, parents, and offspring, as well as siblings.

\section{Testosterone and Oxytocin in Bank Voles}

The father's curse dilemma is exemplified by two hormones, $\mathrm{T}$ and OXT (fig. 2). For the case of T, male bank voles benefit from higher $\mathrm{T}$ levels during male-male competition and courtship, while for females, selection for lower T levels results in higher mating rates, which increases their reproductive success (Mills et al. 2009, 2012; Mokkonen et al. 2012). In bank voles, selection for greater male behavioral dominance (in male-male competition) results in (high-T) sisters with reduced litter sizes as well as reduced postnatal maternal care, characterized by lower growth of sons during the period between birth and weaning (Mokkonen et al. 2011; fig. 3). However, as adults, these sons have significantly greater $\mathrm{T}$ levels, which is correlated with greater mating and reproductive success and contrasts with reduced reproductive success of sisters (Mokkonen et al. 2011). Thus, for a male, the dilemma is that females that have high- $T$ alleles will provide less effective parental care (characterized by lower postnatal growth; fig. 3), which may result in fewer offspring surviving to adulthood, whereas those high- $\mathrm{T}$ alleles being transmitted to offspring will also result in surviving sons having greater future reproductive success.

For the case of OXT, the situation is reversed: females with greater OXT levels are predicted to produce more offspring and provide better care to offspring that results in

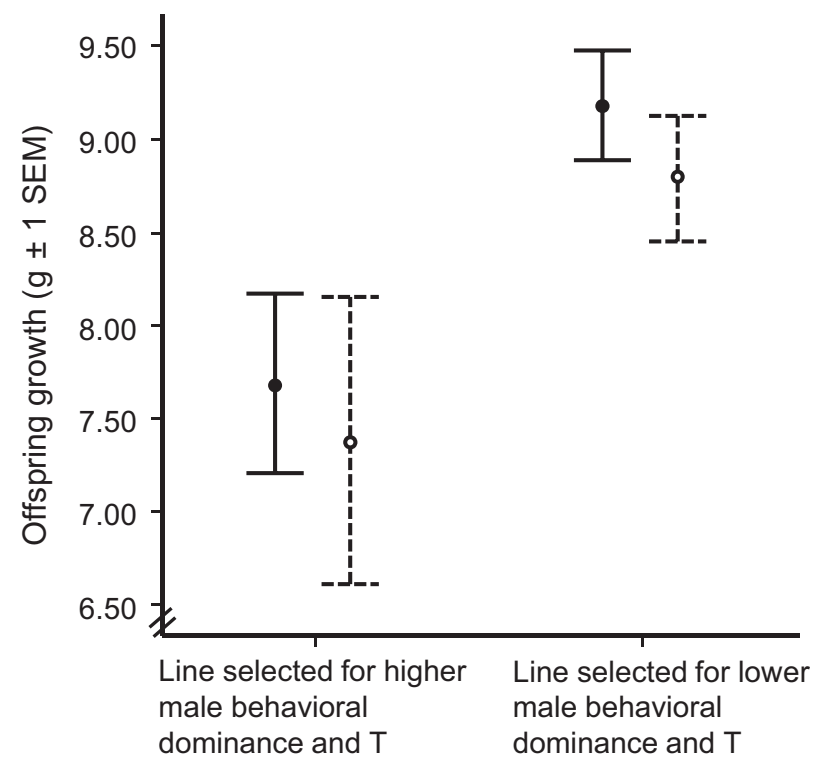

Figure 3: In bank voles, sexually antagonistic selection on male dominance behavior produces families in which mothers provision less during postnatal care and sons have higher relative testosterone (T) values. Females in the "higher male dominance and T" line had lower reproductive success, while females in the "lower male dominance and T" line had higher reproductive success (Mokkonen et al. 2011). Females were artificially selected under principles of sexually antagonistic selection: the brothers were selected for male dominance behavior in reproductive competition, which also resulted in dominant males having significantly greater $\mathrm{T}$ levels compared to subordinate males (Mokkonen et al. 2011). Sons (filled circles and solid lines) and daughters (open circles and dashed lines) had greater growth during postnatal parental care from "good" females in the line selected for subordinate males with lower $\mathrm{T}$ (generalized linear mixed model: line: $F_{1,70}=5.72, P=.019$; sex: $F_{1,70}=6.69, P=$ .012 , litter size: $F_{1,70}=0.66, P=.42$ ). Offspring growth (20-dayold body mass - birth body mass) was the dependent variable, "line" and "sex" were fixed factors, the "litter size" was the covariate, and the "mother identity" was treated as a random effect. Further details on animal husbandry procedures and selection are described elsewhere (Mokkonen et al. 2011).

better survival during the postnatal period of care (Lonn et al. 2017). Males selected for higher OXT are predicted to fare worse in male-male competition and suffer reduced reproductive success due to the action of OXT in promoting affiliative behaviors (Mokkonen and Crespi 2015; Crespi 2016; Lonn et al. 2017). Evidence supporting these predictions is found in recent empirical work on the bank vole that has characterized a microsatellite in the promoter region of the oxytocin receptor locus $(O x t r)$, whereby the number of repeats in the promoter microsatellite directly influences the level of gene expression. These data revealed balancing selection acting on the divergent fitness optima for microsatellite length and thus expression level of the gene (Lonn et al. 2017). In terms of the individuals that survive and reproduce in the field, selection favored females with longer (and males with shorter) 
Oxtr allele lengths. Thus, males benefited from lower expression of Oxtr and presumably less activity of OXT, in terms of their survival and reproductive success. Given how OXT mediates parent-offspring bonding and provisioning of resources through lactation, greater OXT production is predicted to result in better-quality parental care (Lee et al. 2009; McCall and Singer 2012). Thus, for a male, the dilemma is that females that have high-OXT alleles will provide better care to offspring that result in greater offspring recruitment but will also result in sons having reduced future reproductive success. For both of these hormones, their positive effect on maternal care (i.e., greater OXT, lower T) is predicted to trade off with their negative effect on the reproductive success of males.

\section{Predictions, Fitness Outcomes, and Conclusions}

While this father's curse dilemma has been outlined for the general case of hormones in mammals and specifically for bank voles, given the widespread prevalence of hormonally mediated sexual conflicts in mammals (Mokkonen and Crespi 2015; Mokkonen et al. 2016), this phenomenon can be generalized to other taxa and traits that experience trade-offs between mating and parental efforts. Essentially, any trait or locus that results in a fitness trade-off between mating and parental effort between related individuals would be subject to the father's curse dilemma. Natural selection optimizes traits for greater survival, which can constrain adaptation in traits that improve reproductive success. Conversely, sexual selection optimizes traits for greater reproductive success, often at the expense of survival (Kokko and Brooks 2003). Thus, we predict trade-offs between social traits that improve survival and reproductive traits that increase reproductive success through mating or parental effort.

The wealth of research in sexual-conflict theory indicates that sexually antagonistic traits and associated genetic variation should be ubiquitous within the genome and across taxa, though empirical data are still lagging behind the theory (Chapman et al. 2003; Arnqvist and Rowe 2005; Bonduriansky and Chenoweth 2009; van Doorn 2009; Pennell and Morrow 2013; Rice 2013; Rowe et al. 2018). Emerging challenges include identifying the genetic loci associated with sexually antagonistic phenotypes and assessing the prevalence of genetic pleiotropy associated with such sexually antagonistic genetic variation. Bioinformatic tools such as gene ontology assays may allow pleiotropy to be more efficiently characterized (Ashburner et al. 2000). Even if the identified sexually antagonistic loci are pleiotropic but do not impact parental effort per se, this information would provide a more comprehensive understanding of the fitness benefits and costs of the evolutionary conflict.

Genetic evidence of the father's curse is limited; however, focusing on the gene regulatory regions for T, OXT, and AVP hormone receptors may yield further insights into this evolutionary phenomenon. In mammals, the lengths of microsatellite sequences in the $5^{\prime}$ regulatory region upstream of the coding region for these receptor genes correspond to the level of gene expression in a growing number of mammalian taxa (Hammock and Young 2005; Donaldson and Young 2013; Keane et al. 2014; Lonn et al. 2017). Mounting evidence indicates that these receptor genes - AR, Avpr $1 a$, and $O x t r$ - experience sexually antagonistic selection and mediate mating and parental efforts (Summers and Crespi 2008; Lonn et al. 2017). However, challenges still abound: for example, the prevalence of regulatory region-associated microsatellites for the oxytocin receptor gene remains unresolved, as the Oxtr microsatellite has only recently been characterized (Lonn et al. 2017) and appears to be lacking in other studied mammalian species despite the known relevance of this regulatory region for gene expression (Inoue et al. 1994; Young et al. 1997). Data are also needed that relate hormone receptor microsatellite polymorphisms with the quality of parental care provided by mothers and how the reproductive fitness of male offspring is associated with this relationship (taking into account potential confounding maternal effects). The mediating effects of the hormones T and OXT present an evolutionary dilemma between mating and parental efforts, and we have used these hormone systems here as examples of the father's curse. While we have focused on these examples of loci in hormonal pleiotropy, it is conceivable that other pleiotropic loci that exhibit sex-differential effects on mating and parental efforts would be candidate genes for participation in a father's-curse-dilemma form of conflict. Nonetheless, the evolutionary conflict characterized by the father's curse dilemma supports the perspective that relationships between kin need to be further incorporated to better understand the nature of evolutionary conflicts (Haig 2014; Mokkonen et al. 2016; Faria et al. 2017).

During reproduction, fitness constraints manifest in sexual conflicts between mates and conflicts between parent and offspring because of the differences in maternal/paternal and maternal/progeny interests, respectively (Parker et al. 2002; Mokkonen et al. 2016; Rowe et al. 2018). An implication of the close relatedness between parent and offspring is the fact that the individuals in conflict share a high proportion of genes (e.g., $50 \%$ of autosomes and the x chromosome shared between mothers and sons), which differentiates this type of evolutionary conflict from interlocus sexual conflicts. Any evolutionary modification of a parental trait that negatively impacts the survival of offspring will therefore indirectly harm the fitness of the parent as well. Thus, we predict that the fitness trade-off between male mating effort and female parental effort arising from the father's curse dilemma will be akin to fitness trade-offs arising in parent-offspring conflicts and (cross-generational) intralocus sexual conflicts, whereby the survival and recruitment of the offspring influ- 
ences the parent's fitness. Nonetheless, in the father's curse dilemma, while the father exerts a deleterious direct genetic effect on the future parental effort of daughters, the mother exerts two different effects on the fitness of sons: a beneficial indirect genetic effect mediated by maternal investment and a deleterious direct genetic effect on future reproductive success of sons. Thus, a never-ending fitness constraint in reproduction is borne by males.

\section{Acknowledgments}

We thank Locke Rowe for organizing this symposium and providing constructive feedback on this work. We also thank two anonymous reviewers and members of the Crawford Lab for Evolutionary Studies for providing helpful feedback on the manuscript. This work was financially supported by the Academy of Finland and the Natural Sciences and Engineering Research Council.

\section{Literature Cited}

Adkins-Regan, E. 2005. Hormones and animal social behavior. Princeton University Press, Princeton, NJ.

Aloise King, E. D., P. B. Banks, and R. C. Brooks. 2013. Sexual conflict in mammals: consequences for mating systems and life history. Mammal Review 43:47-58.

Alvergne, A., C. Faurie, and M. Raymond. 2009. Variation in testosterone levels and male reproductive effort: insight from a polygynous human population. Hormones and Behavior 56:491-497.

Andersson, M. 1994. Sexual selection. Princeton University Press, Princeton, NJ.

Arnqvist, G., and L. Rowe. 2005. Sexual conflict. Princeton University Press, Princeton, NJ.

Ashburner, M., C. A. Ball, J. A. Blake, D. Botstein, H. Butler, J. M. Cherry, A. P. Davis, et al. 2000. Gene ontology: tool for the unification of biology. Nature Genetics 25:25-29.

Bales, K. L., L. A. Pfeifer, and C. S. Carter. 2004. Sex differences and developmental effects of manipulations of oxytocin on alloparenting and anxiety in prairie voles. Developmental Psychobiology 44:123-131.

Bendesky, A., Y.-M. Kwon, J.-M. Lassance, C. L. Lewarch, S. Yao, B. K. Peterson, M. X. He, C. Dulac, and H. E. Hoekstra. 2017. The genetic basis of parental care evolution in monogamous mice. Nature 544:434-439.

Bonduriansky, R., and S. F. Chenoweth. 2009. Intralocus sexual conflict. Trends in Ecology and Evolution 24:280-288.

Bujalska, G., and L. Hansson. 2000. Bank vole biology: recent advances in the population biology of a model species. Polish Journal of Ecology 48:5-7.

Calcagnoli, F., J. C. Kreutzmann, S. F. de Boer, M. Althaus, and J. M. Koolhaas. 2015. Acute and repeated intranasal oxytocin administration exerts anti-aggressive and pro-affiliative effects in male rats. Psychoneuroendocrinology 51:112-121.

Cavanaugh, J., A. C. Mustoe, J. H. Taylor, and J. A. French. 2014. Oxytocin facilitates fidelity in well-established marmoset pairs by reducing sociosexual behavior toward opposite-sex strangers. Psychoneuroendocrinology 49:1-10.
Cavigelli, S. A., and M. E. Pereira. 2000. Mating season aggression and fecal testosterone levels in male ring-tailed lemurs (Lemur catta). Hormones and Behavior 37:246-255.

Chapman, T., G. Arnqvist, J. Bangham, and L. Rowe. 2003. Sexual conflict. Trends in Ecology and Evolution 18:41-47.

Chippindale, A. K., J. R. Gibson, and W. R. Rice. 2001. Negative genetic correlation for adult fitness between sexes reveals ontogenetic conflict in Drosophila. Proceedings of the National Academy of Sciences of the USA 98:1671-1675.

Cho, M. M., A. C. DeVries, J. R. Williams, and C. S. Carter. 1999. The effects of oxytocin and vasopressin on partner preferences in male and female prairie voles (Microtus ochrogaster). Behavioral Neuroscience 113:1070-1079.

Chunwang, L., J. Zhigang, Z. Yan, and Y. Caie. 2004. Relationship between serum testosterone, dominance and mating success in Père David's deer stags. Ethology 110:681-691.

Clark, M. M., and J. B. G. Galef. 1999. A testosterone-mediated trade-off between parental and sexual effort in male Mongolian gerbils (Meriones unguiculatus). Journal of Comparative Psychology 113:388-395.

Clarke, J. R., F. V. Clulow, and F. Grieg. 1970. Ovulation in the bank vole, Clethrionomys glareolus. Journal of Reproduction and Fertility 23:531.

Clutton-Brock, T. H. 1991. The evolution of parental care. Princeton University Press, Princeton, NJ.

. 2007. Sexual selection in males and females. Science 318:18821885.

Cox, R. M., and R. Calsbeek. 2009. Sexually antagonistic selection, sexual dimorphism, and the resolution of intralocus sexual conflict. American Naturalist 173:176-187.

Cox, R. M., D. S. Stenquist, J. P. Henningsen, and R. Calsbeek. 2009. Manipulating testosterone to assess links between behavior, morphology, and performance in the brown anole Anolis sagrei. Physiological and Biochemical Zoology 82:686-698.

Crespi, B. J. 2016. Oxytocin, testosterone, and human social cognition. Biological Reviews 91:390-408.

Dawson, K. J. 1996. Evolutionary consequences of a trade-off between parental effort and mating effort. $\underline{\text { Journal of Theoretical Bi- }}$ ology 183:139-158.

Dhakar, M. B., M. E. Rich, E. L. Reno, H. J. Lee, and H. K. Caldwell. 2012. Heightened aggressive behavior in mice with lifelong versus postweaning knockout of the oxytocin receptor. Hormones and Behavior 62:86-92.

Donaldson, Z. R., and L. J. Young. 2008. Oxytocin, vasopressin, and the neurogenetics of sociality. Science 322:900-904.

- 2013. The relative contribution of proximal 5' flanking sequence and microsatellite variation on brain vasopressin 1a receptor (Avpr1a) gene expression and behavior. PLoS Genetics 9:e1003729.

Edwards, K. L., S. Shultz, M. Pilgrim, and S. L. Walker. 2015. Male reproductive success is correlated with testosterone in the eastern black rhinoceros (Diceros bicornis michaeli). General and Comparative Endocrinology 213:40-49.

Endendijk, J. J., E. T. Hallers-Haalboom, M. G. Groeneveld, S. R. van Berkel, L. D. van der Pol, M. J. Bakermans-Kranenburg, and J. Mesman. 2016. Diurnal testosterone variability is differentially associated with parenting quality in mothers and fathers. Hormones and Behavior 80:68-75.

Faria, G. S., S. A. M. Varela, and A. Gardner. 2017. Sexual selection modulates genetic conflicts and patterns of genomic imprinting. Evolution 71:526-540. 
Feldman, R., I. Gordon, I. Schneiderman, O. Weisman, and O. Zagoory-Sharon. 2010. Natural variations in maternal and paternal care are associated with systematic changes in oxytocin following parent-infant contact. Psychoneuroendocrinology 35:11331141.

Feldman, R., O. Zagoory-Sharon, O. Weisman, I. Schneiderman, I. Gordon, R. Maoz, I. Shalev, and R. P. Ebstein. 2012. Sensitive parenting is associated with plasma oxytocin and polymorphisms in the OXTR and CD38 genes. Biological Psychiatry 72:175-181.

Finkenwirth, C., E. Martins, T. Deschner, and J. M. Burkart. 2016. Oxytocin is associated with infant-care behavior and motivation in cooperatively breeding marmoset monkeys. Hormones and Behavior 80:10-18.

Fitzpatrick, M. J. 2004. Pleiotropy and the genomic location of sexually selected genes. American Naturalist 163:800-808.

Garver-Apgar, C. E., M. A. Eaton, J. M. Tybur, and M. Emery Thompson. 2011. Evidence of intralocus sexual conflict: physically and hormonally masculine individuals have more attractive brothers relative to sisters. Evolution and Human Behavior 32:423-432.

Gerlach, N. M., and E. D. Ketterson. 2013. Experimental elevation of testosterone lowers fitness in female dark-eyed juncos. Hormones and Behavior 63:782-790.

Gettler, L. T., T. W. McDade, A. B. Feranil, and C. W. Kuzawa. 2011. Longitudinal evidence that fatherhood decreases testosterone in human males. Proceedings of the National Academy of Sciences of the USA 108:16194-16199.

Godfray, H. C. J., and G. A. Parker. 1992. Sibling competition, parent-offspring conflict and clutch size. Animal Behaviour 43 473-490.

Gordon, I., O. Zagoory-Sharon, J. F. Leckman, and R. Feldman. 2010. Oxytocin and the development of parenting in humans. Biological Psychiatry 68:377-382.

Goymann, W., and P. Flores Dávila. 2017. Acute peaks of testosterone suppress paternal care: evidence from individual hormonal reaction norms. Proceedings of the Royal Society B 284:20170632.

Gray, P. B. 2003. Marriage, parenting, and testosterone variation among Kenyan Swahili men. American Journal of Physical Anthropology 122:279-286.

Gray, P. B., S. M. Kahlenberg, E. S. Barrett, S. F. Lipson, and P. T. Ellison. 2002. Marriage and fatherhood are associated with lower testosterone in males. Evolution and Human Behavior 23:193-201.

Haig, D. 2004. Genomic imprinting and kinship: how good is the evidence? Annual Review of Genetics 38:553-585.

. 2014. Coadaptation and conflict, misconception and muddle, in the evolution of genomic imprinting. Heredity 113:96-103

Hammock, E. A. D. 2015. Developmental perspectives on oxytocin and vasopressin. Neuropsychopharmacology 40:24-42.

Hammock, E. A. D., and L. J. Young. 2005. Microsatellite instability generates diversity in brain and sociobehavioral traits. Science 308 $1630-1634$

Hansson, L. 1979. Condition and diet in relation to habitat in bank voles Clethrionomys glareolus: population or community approach? Oikos 33:55-63.

Hau, M., and J. C. Wingfield. 2011. Hormonally-regulated trade-offs: evolutionary variability and phenotypic plasticity in testosterone signalling pathways. Pages 349-361 in T. Flatt and A. Heyland, eds. Mechanisms of life history evolution. Oxford University Press, Oxford.

Inoue, T., T. Kimura, C. Azuma, J. Inazawa, M. Takemura, T. Kikuchi, Y. Kubota, K. Ogita, and F. Saji. 1994. Structural organization of the human oxytocin receptor gene. Journal of Biological Chemistry 269:32451-32456.

James, P. J., and J. G. Nyby. 2002. Testosterone rapidly affects the expression of copulatory behavior in house mice (Mus musculus). Physiology and Behavior 75:287-294.

John-Alder, H. B., R. M. Cox, G. J. Haenel, and L. C. Smith. 2009 Hormones, performance and fitness: natural history and endocrine experiments on a lizard (Sceloporus undulatus). Integrative and Comparative Biology 49:393-407.

Johnson, Z. V., H. Walum, Y. A. Jamal, Y. Xiao, A. C. Keebaugh, K. Inoue, and L. J. Young. 2016. Central oxytocin receptors mediate mating-induced partner preferences and enhance correlated activation across forebrain nuclei in male prairie voles. Hormones and Behavior 79:8-17.

Keane, B., S. Parsons, B. J. Smucker, and N. G. Solomon. 2014. Length polymorphism at the avprla locus is correlated with male reproductive behavior in a natural population of prairie voles (Microtus ochrogaster). Behavioral Ecology and Sociobiology 68:1951-1964.

Ketterson, E. D., and V. Nolan. 1999. Adaptation, exaptation, and constraint: a hormonal perspective. American Naturalist 154(suppl.): S4-S25.

Kokko, H., and R. Brooks. 2003. Sexy to die for? sexual selection and the risk of extinction. Annales Zoologici Fennici 40:207-219.

Kokko, H., and M. D. Jennions. 2008. Parental investment, sexual selection and sex ratios. Journal of Evolutionary Biology 21:919-948.

Koskela, E., T. Mappes, and H. Ylonen. 1997. Territorial behaviour and reproductive success of bank vole Clethrionomys glareolus females. Journal of Animal Ecology 66:341-349.

Kuzawa, C. W., L. T. Gettler, Y. Y. Huang, and T. W. McDade. 2010 Mothers have lower testosterone than non-mothers: evidence from the Philippines. Hormones and Behavior 57:441-447.

Kuzawa, C. W., L. T. Gettler, M. N. Muller, T. W. McDade, and A. B. Feranil. 2009. Fatherhood, pairbonding and testosterone in the Philippines. Hormones and Behavior 56:429-435.

Lee, H. J., A. H. Macbeth, J. H. Pagani, and W. S. Young. 2009. Oxytocin the great facilitator of life. Progress in Neurobiology 88:127-151.

Lemaître, J.-F., S. A. Ramm, J. L. Hurst, and P. Stockley. 2011. Social cues of sperm competition influence accessory reproductive gland size in a promiscuous mammal. Proceedings of the Roval Society B 278:1171-1176.

. 2012. Sperm competition roles and ejaculate investment in a promiscuous mammal. Journal of Evolutionary Biology 25:12161225.

Lemaître, J.-F., S. A. Ramm, N. Jennings, and P. Stockley. 2012. Genital morphology linked to social status in the bank vole (Myodes glareolus). Behavioral Ecology and Sociobiology 66:97-105.

Li, T., X. Chen, J. Mascaro, E. Haroon, and J. K. Rilling. 2017. Intranasal oxytocin, but not vasopressin, augments neural responses to toddlers in human fathers. Hormones and Behavior 93:193-202.

Lonn, E., E. Koskela, T. Mappes, M. Mokkonen, A. M. Sims, and P. C. Watts. 2017. Balancing selection maintains polymorphisms at neurogenetic loci in field experiments. Proceedings of the National Academv of Sciences of the USA 114:3690-3695.

Lukas, D., and T. Clutton-Brock. 2012. Cooperative breeding and monogamy in mammalian societies. Proceedings of the Roval Society B 279:2151-2156

Madden, J. R., and T. H. Clutton-Brock. 2011. Experimental peripheral administration of oxytocin elevates a suite of cooperative behaviours in a wild social mammal. Proceedings of the Roval Society B 278:1189-1194. 
Malo, A. F., E. R. S. Roldan, J. J. Garde, A. J. Soler, J. Vicente, C. Gortazar, and M. Gomendio. 2009. What does testosterone do for red deer males? Proceedings of the Roval Societv B 276:971-980.

Mank, J. E., L. Hultin-Rosenberg, M. Zwahlen, and H. Ellegren. 2008. Pleiotropic constraint hampers the resolution of sexual antagonism in vertebrate gene expression. American Naturalist 171:35-43.

Mascaro, J. S., P. D. Hackett, and J. K. Rilling. 2013. Testicular volume is inversely correlated with nurturing-related brain activity in human fathers. Proceedings of the National Academv of Sciences of the USA 110:15746-15751.

McCall, C., and T. Singer. 2012. The animal and human neuroendocrinology of social cognition, motivation and behavior. Nature Neuroscience 15:681-688.

McGlothlin, J. W., J. M. Jawor, and E. D. Ketterson. 2007. Natural variation in a testosterone-mediated trade-off between mating effort and parental effort. American Naturalist 170:864-875.

McGuigan, K., L. Rowe, and M. W. Blows. 2011. Pleiotropy, apparent stabilizing selection and uncovering fitness optima. Trends in Ecology and Evolution 26:22-29.

McNamara, J. M., and M. Wolf. 2015. Sexual conflict over parental care promotes the evolution of sex differences in care and the ability to care. Proceedings of the Roval Societv B 282:20142752.

Meunier, J., and M. Kolliker. 2012. Parental antagonism and parentoffspring co-adaptation interact to shape family life. Proceedings of the Roval Society B 279:3981-3988.

Mills, S. C., A. Grapputo, I. Jokinen, E. Koskela, T. Mappes, T. A. Oksanen, and T. Poikonen. 2009. Testosterone-mediated effects on fitness-related phenotypic traits and fitness. American Naturalist 173:475-487.

Mills, S. C., A. Grapputo, E. Koskela, and T. Mappes. 2007. Quantitative measure of sexual selection with respect to the operational sex ratio: a comparison of selection indices. Proceedings of the Roval Society B 274:143-150.

Mills, S. C., E. Koskela, and T. Mappes. 2012. Intralocus sexual conflict for fitness: sexually antagonistic alleles for testosterone. Proceedings of the Roval Society B 279:1889-1895.

Mills, S. C., M. Mokkonen, E. Koskela, and T. Mappes. 2014 Genotype-by-environment interactions and reliable signaling of male quality in bank voles. Pages 241-264 in J. Hunt and D. Hosken, eds. Genotype-by-environment interactions and sexual selection. Wiley, Oxford.

Mokkonen, M., and B. Crespi. 2015. Genomic conflicts and sexual antagonism in human health: insights from oxytocin and testosterone. Evolutionary Applications 8:307-325.

Mokkonen, M., H. Kokko, E. Koskela, J. Lehtonen, T. Mappes, H. Martiskainen, and S. C. Mills. 2011. Negative frequency-dependent selection of sexually antagonistic alleles in Myodes glareolus. Science 334:972-974.

Mokkonen, M., E. Koskela, T. Mappes, and S. C. Mills. 2012. Sexual antagonism for testosterone maintains multiple mating behaviour. Journal of Animal Ecology 81:277-283.

- 2016. Evolutionary conflict between maternal and paternal interests: integration with evolutionary endocrinology. Integrative and Comparative Biology 56:146-158.

Muller, M. N., F. W. Marlowe, R. Bugumba, and P. T. Ellison. 2009. Testosterone and paternal care in East African foragers and pastoralists. Proceedings of the Roval Society B 276:347-354.

Nunes, S., J. E. Fite, and J. A. French. 2000. Variation in steroid hormones associated with infant care behaviour and experience in male marmosets (Callithrix kuhlii). Animal Behaviour 60:857-865.
Onyango, P. O., L. R. Gesquiere, J. Altmann, and S. C. Alberts. 2013 Testosterone positively associated with both male mating effort and paternal behavior in savanna baboons (Papio cynocephalus). Hormones and Behavior 63:430-436.

Ophir, A. G., A. Gessel, D.-J. Zheng, and S. M. Phelps. 2012. Oxytocin receptor density is associated with male mating tactics and social monogamy. Hormones and Behavior 61:445-453.

Parker, G. A., N. J. Royle, and I. R. Hartley. 2002. Intrafamilial conflict and parental investment: a synthesis. Philosophical Transactions of the Roval Society B 357:295-307.

Parker, K. J., L. F. Kinney, K. M. Phillips, and T. M. Lee. 2001. Paternal behavior is associated with central neurohormone receptor binding patterns in meadow voles (Microtus pennsylvanicus). $\underline{\text { Be- }}$ havioral Neuroscience 115:1341-1348.

Patten, M. M., L. Ross, J. P. Curley, D. C. Queller, R. Bonduriansky, and J. B. Wolf. 2014. The evolution of genomic imprinting: theories, predictions and empirical tests. Heredity 113:119-128.

Patten, M. M., F. Ubeda, and D. Haig. 2013. Sexual and parental antagonism shape genomic architecture. Proceedings of the Roval Society B 280:20131795.

Pennell, T. M., and E. H. Morrow. 2013. Two sexes, one genome: the evolutionary dynamics of intralocus sexual conflict. Ecology and Evolution 3:1819-1834.

Peters, M., L. W. Simmons, and G. Rhodes. 2008. Testosterone is associated with mating success but not attractiveness or masculinity in human males. Animal Behaviour 76:297-303.

Peterson, M. P., K. A. Rosvall, C. A. Taylor, J. A. Lopez, J. H. Choi, C. Ziegenfus, H. X. Tang, J. K. Colbourne, and E. D. Ketterson. 2014. Potential for sexual conflict assessed via testosterone-mediated transcriptional changes in liver and muscle of a songbird. Lournal of Experimental Biology 217:507-517.

Pischedda, A., and A. K. Chippindale. 2006. Intralocus sexual conflict diminishes the benefits of sexual selection. PLoS Biology 4:e356.

Poikonen, T., E. Koskela, T. Mappes, and S. C. Mills. 2008. Infanticide in the evolution of reproductive synchrony: effects on reproductive success. Evolution 62:612-621.

Prudom, S. L., C. A. Broz, N. Schultz-Darken, C. T. Ferris, C. Snowdon, and T. E. Ziegler. 2008. Exposure to infant scent lowers serum testosterone in father common marmosets (Callithrix jacchus). Biology Letters 4:603-605.

Queller, D. C. 1997. Why do females care more than males? Proceedings of the Roval Societv B 264:1555-1557.

Reynolds, J. D., N. B. Goodwin, and R. P. Freckleton. 2002. Evolutionary transitions in parental care and live bearing in vertebrates. Philosophical Transactions of the Roval Societv B 357:269-281.

Rice, W. R. 2013. Nothing in genetics makes sense except in light of genomic conflict. Annual Review of Ecology, Evolution, and Systematics 44:217-237.

Rice, W. R., and A. K. Chippindale. 2001. Intersexual ontogenetic conflict. Journal of Evolutionary Biology 14:685-693.

Roney, J. R., and L. T. Gettler. 2015. The role of testosterone in human romantic relationships. Current Opinion in Psychology 1:81-86.

Rosvall, K. A. 2013. Life history trade-offs and behavioral sensitivity to testosterone: an experimental test when female aggression and maternal care co-occur. PLoS ONE 8:e54120.

Rosvall, K. A., C. M. B. Burns, J. Barske, J. L. Goodson, B. A. Schlinger, D. R. Sengelaub, and E. D. Ketterson. 2012. Neural sensitivity to sex steroids predicts individual differences in aggression: implications for behavioural evolution. Proceedings of the Roval Society B 279: 3547-3555. 
Rowe, L., S. F. Chenoweth, and A. F. Agrawal. 2018. The genomics of sexual conflict. American Naturalist (forthcoming).

Royle, N. J., I. R. Hartley, and G. A. Parker. 2004. Parental investment and family dynamics: interactions between theory and empirical tests. Population Ecology 46:231-241.

Saito, A., and K. Nakamura. 2011. Oxytocin changes primate paternal tolerance to offspring in food transfer. Iournal of Comparative Physiology A 197:329-337.

Saldivar Lemus, Y., J.-P. Vielle-Calzada, M. G. Ritchie, and C. Macías Garcia. 2017. Asymmetric paternal effect on offspring size linked to parent-of-origin expression of an insulin-like growth factor. Ecology and Evolution 7:4465-4474.

Saltzman, W., and T. E. Ziegler. 2014. Functional significance of hormonal changes in mammalian fathers. Journal of Neuroendocrinology 26:685-696.

Shuster, S. M., and M. J. Wade. 2003. Mating systems and strategies. Princeton University Press, Princeton, NJ.

Smith, A. S., A. Ågmo, A. K. Birnie, and J. A. French. 2010. Manipulation of the oxytocin system alters social behavior and attraction in pairbonding primates, Callithrix penicillata. Hormones and Behavior 57:255-262

Stiver, K. A., and S. H. Alonzo. 2009. Parental and mating effort: is there necessarily a trade-off? Ethology 115:1101-1126.

Summers, K., and B. Crespi. 2008. The androgen receptor and prostate cancer: a role for sexual selection and sexual conflict? Medical Hypotheses 70:435-443.

Taylor, J. H., and J. A. French. 2015. Oxytocin and vasopressin enhance responsiveness to infant stimuli in adult marmosets. Hormones and Behavior 75:154-159.

Trivers, R. L. 1972. Parental investment and sexual selection. Pages 136-179 in B. Campbell, ed. Sexual selection and the descent of man. Aladine, Chicago.

- 1974. Parent-offspring conflict. American Zoologist 14:249264.

van Anders, S. M., L. D. Hamilton, and N. V. Watson. 2007. Multiple partners are associated with higher testosterone in North American men and women. Hormones and Behavior 51:454-459. van Doorn, G. S. 2009. Intralocus sexual conflict. Annals of the New York Academy of Sciences 1168:52-71.

Walling, C. A., C. E. Stamper, P. T. Smiseth, and A. J. Moore. 2008. The quantitative genetics of sex differences in parenting. Proceedings of the National Academv of Sciences of the USA 105:1843018435.

Wedell, N., C. Kvarnemo, C. M. Lessells, and T. Tregenza. 2006. Sexual conflict and life histories. Animal Behaviour 71:999-1011.

Williams, G. C. 1957. Pleiotropy, natural selection and the evolution of senescence. Evolution 11:398-411.

Wingfield, J. C., R. E. Hegner, A. M. Dufty Jr., and G. F. Ball. 1990 The "challenge hypothesis": theoretical implications for patterns of testosterone secretion, mating systems, and breeding strategies. American Naturalist 136:829-846.

Ylönen, H., E. Koskela, and T. Mappes. 1997. Infanticide in the bank vole (Clethrionomys glareolus): occurrence and the effect of familiarity on female infanticide. Annales Zoologici Fennici 34:259-266.

Young, L. J., M. M. Lim, B. Gingrich, and T. R. Insel. 2001. Cellular mechanisms of social attachment. Hormones and Behavior 40: 133-138.

Young, L. J., R. Nilsen, K. G. Waymire, G. R. MacGregor, and T. R. Insel. 1999. Increased affiliative response to vasopressin in mice expressing the $V_{1 a}$ receptor from a monogamous vole. Nature 400:766-768.

Young, L. J., K. G. Waymire, R. Nilsen, G. R. Macgregor, Z. Wang, and T. R. Insel. 1997. The $5^{\prime}$ flanking region of the monogamous prairie vole oxytocin receptor gene directs tissue-specific expression in transgenic mice. Annals of the New York Academy of Sciences 807:514-517.

Zysling, D. A., T. J. Greives, C. W. Breuner, J. M. Casto, G. E. Dernas, and E. D. Ketterson. 2006. Behavioral and physiological responses to experimentally elevated testosterone in female darkeyed juncos (Junco hyemalis carolinensis). Hormones and Behavior 50:200-207.

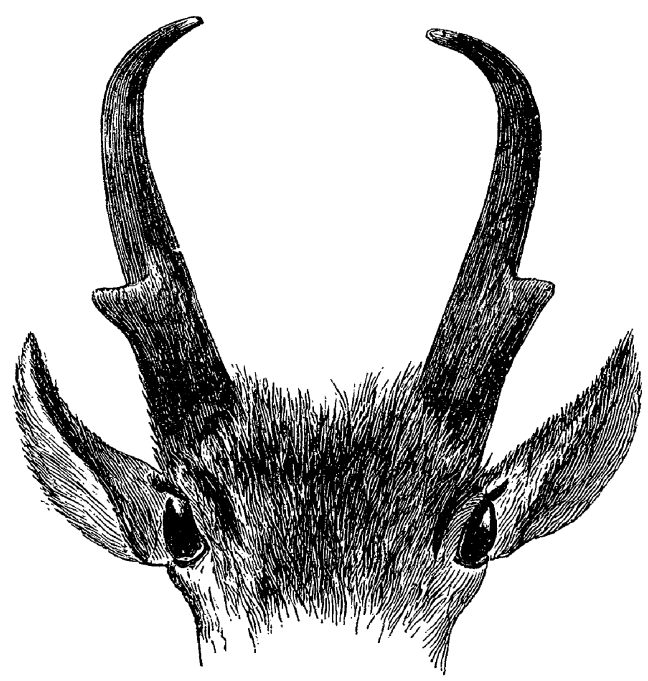

Symposium Editor: Locke Rowe

"The animal, from which I have made the drawings, is now developing his fourth pair of horns. The second pair of horns were about three inches longer than the first, and the same difference existed between the second and third pair." From "The Prong-Horn Antelope" by W. J. Hays (The American Naturalist, 1868, 2:131-133). 